\title{
Do polygyne ants cooperate? : Colony boundaries and larval discrimination in multiple-queen colonies of the red imported fire ant (Solenopsis invicta)
}

\author{
MacKenzie Kjeldgaard ${ }^{1}$, Pierre-André Eyer ${ }^{1}$, Collin McMichael $^{1}$, Alison Bockoven ${ }^{1}$, Joanie \\ King $^{1}$, Ayumi Hyodo ${ }^{1}$, Thomas Boutton ${ }^{1}$, Edward Vargo ${ }^{1}$, and Micky Eubanks ${ }^{1}$ \\ ${ }^{1}$ Texas A\&M University College Station
}

October 9, 2020

\begin{abstract}
Unicoloniality, or the absence of behavioral boundaries between nests, is thought to promote ant abundance due to reduced intraspecific competition. Workers within unicolonial populations may increase their own inclusive fitness by preferentially caring for more related individuals (nepotism), but nepotism has only rarely been documented in ants. We tested for unicoloniality and nepotism in polygyne red imported fire ants (Solenopsis invicta; hereafter fire ants). Fire ants occur in two social forms: monogyne (i.e., colonies with a single egg-laying queen) and polygyne (i.e., colonies with multiple egg-laying queens). Introduced populations of polygyne fire ants are commonly referred to as unicolonial, but cooperation between and within colonies is poorly documented. To delimit boundaries between colonies in the field, we quantified the exchange of a ${ }^{15} \mathrm{~N}$-glycine tracer dissolved in a sucrose solution and correlated this exchange with colony genetic structure. We also quantified within-colony conflict between workers and larvae using close siblings (i.e., from the same mother) and non-siblings (i.e., from a different mother). Counter to our expectations, polygyne colonies did not exchange resources or workers, indicating distinct colony boundaries. Polygyne workers also preferentially fed larval sibling and may have preferentially cannibalized non-siblings. Polygyne colony behavior was correlated with higher levels of within-mound relatedness between workers in the field than those previously reported in North America (mean \pm SE: $0.269 \pm 0.037$ ). Our study challenges fundamental assumptions about introduced populations of polygyne fire ants and suggests that polygyne colonies are multicolonial and likely engage in high levels of intraspecific competition.
\end{abstract}

\section{Keywords}

Unicoloniality, isotope tracer, invasive ant, microsatellites, population genetics, nepotism

\section{Introduction}

Invasive ants often reach extremely high densities, outcompete and prey upon native species, disrupt mutualisms, and lower ecosystem biodiversity (Berman, Andersen, Hély, \& Gaucherel, 2013; Holway, 1998; Holway, Lach, Suarez, Tsutsui, \& Case, 2002; LeBrun, Abbott, \& Gilbert, 2013; McGlynn, 1999; Porter \& Savignano, 1990). Understanding the factors that promote the success of invasive ants is critical to defining and managing their ecological impacts. One factor thought to play a role in invasive ant success is their proclivity for intraspecific cooperation (Holway et al., 2002; Passera, 1994). Many invasive ant species are unicolonial in their introduced range, meaning that populations are characterized by an absence of behavioral boundaries among nests (Helanterä, Strassmann, Carrillo, \& Queller, 2009; Holway et al., 2002; Krushelnycky, Holway, \& LeBrun, 2010). By cooperating instead of competing with conspecifics, unicolonial ants avoid the costs of intraspecific competition, which is thought to allow them to reach higher densities (Giraud, Pedersen, \& Keller, 2002; Porter, Fowler, \& Mackay, 1992) and achieve greater ecological dominance by more effectively 
outcompeting other species (Holway et al., 2002; Holway \& Suarez, 2004; LeBrun et al., 2013). For example, the number of Argentine ant workers (Linepithema humile) was approximately 50-fold higher in sites where nests cooperated compared with sites where nests competed (Holway \& Suarez, 2004). Consequently, cooperative Argentine ants more effectively outcompeted native ants, as native ant species richness was reduced by over 50\% when Argentine ant nests cooperated compared with when they competed with each other (Holway \& Suarez, 2004). The positive correlation between instraspecific cooperation and ecological impact has also been implicated in other social insects (Hanna et al., 2014; Korb \& Foster, 2010; Perdereau et al., 2015, Wilson, Mullen, \& Holway, 2009).

However, unicoloniality does not explain the success of all invasive ant species (Holway et al., 2002; Passera, 1994). The dark rover ant (Brachymyrmex patagonicus), for example, has invaded large portions of the southern USA (MacGown, Hill, \& Deyrup, 2007), but introduced populations of this species are multicolonial, with distinct nests usually headed by a single egg-laying queen (monogyne; Eyer, Espinoza, Blumenfeld, \& Vargo, 2020). Moreover, despite the ecological benefits, when many unrelated queens cooperate and produce workers within a single colony, relatedness between nestmates can decrease to effectively zero (Crozier \& Pamilo, 1996; Keller, 1995; Queller \& Strassmann, 1998). As a consequence, polygyny and especially unicoloniality increase the likelihood of workers interacting with and caring for less related individuals, which in turn reduces their inclusive fitness (Helanterä et al., 2009; Schmid-Hempel, 1997; Schmid-Hempel \& Crozier, 1999). Inclusive fitness may be maintained, however, if workers discern and preferentially direct care towards kin over non-kin (Hamilton, 1964; Keller, 1995). For example, although Argentine ant supercolonies are characterized by cooperative, interconnected nests (Giraud et al., 2002; Tsutsui, Suarez, Holway, \& Case, 2000), workers spend more time investigating (i.e., antennating) non-nestmates than nestmates from the same supercolony (Björkman-Chiswell, Van Wilgenburg, Thomas, Swearer, \& Elgar, 2008), indicating nestmate recognition despite a lack of aggression within the same supercolony in this species. Nestmate recognition may reduce or eliminate indiscriminate sharing between Argentine ant nests, as sharing was consistently limited to distinct clusters of nests within a single supercolony over a three-year-period (Heller, Ingram, \& Gordon, 2008). Kin recognition can also impact sharing between individuals within the nest in what is known as nepotism. For example, in polygyne ant colonies of Formica argentea, workers preferentially care for brood that are more closely related to them (Snyder, 1993). By discriminately sharing food resources with more related individuals from neighboring mounds or from within the same mound, workers may increase their inclusive fitness in polygyne colonies (Hamilton, 1964; Helanterä et al., 2009). Despite the evolutionary benefits of preferential care towards kin over non-kin, it has only rarely been documented in polygyne or unicolonial ant species and may be less common than previously thought (Boomsma \& d'Ettorre, 2013; Keller, 1997).

We tested for unicoloniality and within-colony nepotism in polygyne red imported fire ants (Solenopsis invicta ; hereafter fire ants). Fire ants occur in two social forms: the polygyne form (i.e., colonies with multiple egglaying queens) and the monogyne form (i.e., colonies with only a single egg-laying queen; Gotzek, Shoemaker, \& Ross, 2007; Ross, 1993; Ross, Vargo, \& Keller, 1996; Tschinkel, 2006). Polygyne fire ant colonies are considered highly cooperative, and they are often referred to as unicolonial throughout their invaded range (e.g., Greenberg, Vinson, \& Ellison, 1992; Holway et al., 2002; Morel, Vander Meer, \& Lofgren, 1990; Plowes, Dunn, \& Gilbert, 2007; Porter et al., 1992; Vander Meer, Obin, \& Morel, 1990). Cooperative behavior in polygyne fire ants is thought to correspond with a greater abundance compared with the monogyne form due to reduced intraspecific competition (Porter, Bhatkar, Mulder, Vinson, \& Clair, 1991). For example, polygyne mounds were over twice as abundant on average compared with monogyne mounds in Texas (mean \pm SE: $680 \pm 475$ polygyne mounds/ha vs. $295 \pm 240$ monogyne mounds/ha; Porter et al., 1991). The greater abundance of the polygyne form may increase the likelihood of ants interacting with and preying upon native species, thereby increasing their ecological impact (Allen, Epperson, \& Garmestani, 2004; Porter \& Savignano, 1990). Despite the assumption that polygyne mounds cooperate and are highly interconnected (see Bhatkar \& Vinson, 1987), the physical exchange of workers and resources between polygyne mounds in the field is actually poorly documented. Moreover, although polygyne workers from different nests do not aggressively attack each other outside of the nest (Vander Meer et al., 1990), their interactions within 
the nest are relatively unknown (but see DeHeer \& Ross, 1997), particularly in the case of worker-brood interactions. Within-colony relatedness between polygyne workers is often near zero throughout their invaded range (DeHeer \& Ross, 1997; Goodisman, Sankovich, \& Kovacs, 2007; Ross, 1993; Ross \& Fletcher, 1985; Ross et al., 1996), but workers may increase their inclusive fitness by preferentially caring for more related brood.

Our study tests fundamental assumptions about inter- and intracolonial cooperation in introduced populations of polygyne fire ants. To delimit boundaries between colonies, we quantified the exchange of $\mathrm{a}^{15} \mathrm{~N}$-glycine tracer dissolved in a sucrose solution and correlated this exchange with colony genetic structure. Using a labeled resource in combination with genetics data allows for two different ways to define colony boundaries (Ellis, Procter, Buckham-Bonnett, \& Robinson, 2017). We also quantified within-colony conflict between workers and larvae by comparing brood-tending behaviors towards close siblings (i.e., from the same mother) and non-siblings (i.e., from a different mother). Studies that actually document cooperation between and within colonies are critical to understanding the ecology and success of invasive species.

\section{Materials and Methods}

\section{Between-mound sharing}

To quantify sharing between mounds in the field, we treated select mounds in each site with a stable isotope tracer and quantified its movement into neighboring mounds (Fig 1). Stable isotope tracers employ naturally occurring, non-radioactive forms of biologically relevant elements, such as nitrogen. The heavier isotope of nitrogen $\left({ }^{15} \mathrm{~N}\right)$ occurs rarely in nature, so by artificially 'spiking' a food with an appropriate concentration of this heavy isotope, we can trace the movement of this isotope through consumers and identify the flow of nutrients through an ecosystem (Fry, 2006). We ensured that only the treated mounds had access to the isotope tracer, so if a neighboring untreated mound showed unnaturally high levels of ${ }^{15} \mathrm{~N}$, this would indicate an exchange of either workers or resources between the treated and untreated mounds (i.e., no boundaries between mounds).

Sampling was conducted between August and October 2019 in six field sites in Texas, USA (Appendix S1). Habitats ranged from restored grasslands (sites O, A, and B) to mowed fields (sites C, T, and T2). Mounds were used as a proxy for individual nests. We identified three clusters of four to five mounds at each site. One mound within each cluster was selected as the treatment mound. Clusters were separated by at least 50 $\mathrm{m}$ within each site to avoid potential sharing between clusters (Fig 1). To determine any effect of distance on resource sharing, untreated mounds within each cluster were between $0.4 \mathrm{~m}-29.07 \mathrm{~m}$ from the treated mound, with an average distance of $7.65 \mathrm{~m} \pm 0.72 \mathrm{~m}$.

Similar to other studies (Goodisman et al., 2007), several fire ant mounds disappeared or moved over the course of the sampling period. As a consequence, we were unable to find three mounds (one mound from site $\mathrm{T}$, one from $\mathrm{O}$, and one from T2) after the treatment period. Each of these were untreated mounds within different clusters, so their removal did not affect the number of clusters analyzed in each location. In total, we sampled from 73 fire ant mounds across six sites, with 12 mounds in Site A, 13 in Site B, 12 in site C, 11 in Site O, 13 in Site T, and 12 in Site T2.

\section{Treatment with the tracer}

We fed each treated mound a nitrogen tracer mixed in sugar water. A solution with $102 \mathrm{mM}$ of ${ }^{15} \mathrm{~N}$-labeled glycine (98 atom\%, Sigma-Aldrich, Inc., St. Louis, MO, USA) and $61.5 \mathrm{mM}$ of unlabeled sucrose was created using distilled water. This concentration was determined based on a preliminary laboratory experiment with a small number of fire ant workers and an approximation of colony sizes in the field, which can exceed 250,000 workers within a single mound (Tschinkel, 2006). The solution was mixed in bulk at the beginning of the field experiment and frozen between uses to avoid mold growth. We filled 1-mL microcentrifuge tubes with $1 \mathrm{~mL}$ of the solution and stoppered each with cotton. Three of these vials were left on the surface of each treatment mound and replaced every other day for 14 days. Vials were placed directly on the mound surface to ensure that only the treated mound fed on the solution. Each treatment mound was fed a total of 160 
$\mathrm{mg}$ of ${ }^{15} \mathrm{~N}$-labeled glycine in $21 \mathrm{~mL}$ of sugar solution over a 14-day period. Fire ant workers were observed feeding on the solution, and there was evidence of mound building over the vial opening, indicating worker foraging.

We collected workers from all treated and untreated mounds once before feeding the tracer to treated mounds and once after the 14-day treatment period (Fig 1). Workers were collected by disturbing a small section of each mound and aspirating 40-50 workers for isotopic and genetic analyses (see Genetic analysis section below). Workers were frozen at $-10 @ \mathrm{C}$. We then transferred 10-30 workers per mound to $95 \% \mathrm{EtOH}$ for storage prior to DNA extraction and left the remaining workers for stable isotope analysis. Workers for stable isotope analysis were never stored in $\mathrm{EtOH}$ to avoid possible effects of $\mathrm{EtOH}$ on isotopic signatures (Tillberg, McCarthy, Dolezal, \& Suarez, 2006).

\section{Stable isotope analyses}

Workers were dried in an oven at 60@C for 24-48 hours and then stored in airtight vials prior to processing. The abdomens of all ants were removed prior to weighing to avoid the effects of stomach contents on isotopic signatures (Tillberg et al., 2006). To achieve appropriate weights for each sample, five to ten workers per sample were pooled and chopped in glass vials to fine homogeneous powders using small scissors (Fig 1). Approximately $0.400 \mathrm{mg}$ of each sample was weighed into tin capsules (Costech Analytical Technologies Inc., Valencia, CA, USA) using a microbalance (Mettler Toledo, Columbus, OH, USA). All samples were analyzed at the Texas A\&M University Stable Isotopes for Biosphere Science Laboratory (https://sibs.tamu.edu/) using a Delta V Advantage Isotope Ratio Mass Spectrometer coupled with a Costech Elemental Analyzer and Thermo ConFlo IV Universal Interface (Thermo Fisher Scientific, Waltham, MA, USA). All baseline samples (collected before mounds were fed the tracer) were analyzed before any post-feeding samples to ensure that natural abundance values were not influenced by memory effects from the high levels of ${ }^{15} \mathrm{~N}$ in spiked samples. Nitrogen isotope ratios are presented in $\delta$ notation:

$\left.\delta^{15} \mathrm{~N}\left(\mathrm{R}_{\text {standard }}\right) / \mathrm{R}_{\text {standard }}\right] \times 10^{3}$

where $R_{\text {sample }}$ is the ${ }^{15} \mathrm{~N} /{ }^{14} \mathrm{~N}$ ratio of the sample and $\mathrm{R}_{\text {standard }}$ is the ${ }^{15} \mathrm{~N} /{ }^{14} \mathrm{~N}$ ratio of the atmospheric $\mathrm{N}$ standard (Mariotti, 1983; Coplen, 2011). Precision was 0.1

To verify that our isotope tracer methods could detect resource sharing over 30-m distances, we conducted a proof of concept experiment using a population of tawny crazy ants (Nylanderia fulva) near College Station, Texas. This species forms a single supercolony throughout its invaded range in North America, in which workers regularly share collected resources with each other and occupy transitory nests (Eyer et al., 2018; Wang et al., 2016). Our results from this experiment confirmed that the isotope tracer is highly successful at detecting sharing in unicolonial populations at distances that were relevant for our study (i.e., up to $28.4 \mathrm{~m}$ from the treated area; Kjeldgaard et al., unpublished data ).

\section{Genetic analyses}

Genetic analyses were used to infer the social structure (i.e., monogyne or polygyne) and genetic relatedness within and between each fire ant mound analyzed (Fig 1). For each mound, eight workers were randomly selected for DNA extraction. DNA was extracted from individual workers following a modified GentraPureGene protocol (Gentra Systems, Inc. Minneapolis, MN, USA).

To determine the social form of each mound, we pooled the DNA extracted from the eight individual workers per mound and screened this pooled sample for the presence of the $G p-9^{b}$ allele, exclusively present in polygyne colonies (Krieger \& Ross, 2002; Ross \& Keller, 1998). A PCR reaction was performed on each pooled sample using the specific primer pair 24bS and 25bAS (Valles \& Porter, 2003). This primer pair amplifies a $423 \mathrm{bp}$ amplicon, and a successful amplification denotes the presence of the $G p-9^{b}$ allele, thereby characterizing the workers as polygyne. Amplifications were performed according to the protocol described in Valles and Porter (2003) and visualized on a 1\% agarose gel. In all, we identified 38 monogyne and 35 polygyne mounds across all six fire ant sites using the $G p-9$ method, of which 11 monogyne and 8 polygyne mounds were treated with the isotope tracer. 
In addition, five microsatellite markers previously developed forS. invicta (Sol11, Sol20 , Sol42 ,Sol49 and Sol55 ; Krieger \& Keller, 1997) were amplified for each of the eight individual workers per mound. The allelic polymorphism of these five microsatellites was previously shown to be suitable to delimit colonies of S. invicta and infer their colony structure. The microsatellites were genotyped using the M13-tailed primer method (Boutin-Ganache, Raposo, Raymond, \& Deschepper, 2001), consisting of 5'-fluorescently labeled tails with 6-FAM, VIC, PET or NED dyes to facilitate multiplexing. DNA amplifications were performed in a volume of $15 \mu \mathrm{L}$ including $0.25-1.0 \mathrm{U}$ of MyTaq HS DNA polymerase (Bioline), $2 \mu \mathrm{L}$ of MyTaq $5 \mathrm{x}$ reaction buffer (Bioline), $0.08 \mu \mathrm{L}$ of each primers, 0.08 of each M13 dye and $1 \mu \mathrm{L}$ of the DNA template. PCR reactions were carried out using a Bio-Rad thermocycler T100 (Bio-Rad, Pleasanton, CA, USA). PCR products were sized against LIZ500 internal standard on an ABI 3500 genetic analyzer (Applied Biosystems, Foster City, CA, USA). Allele calling was performed using Geneious software v.9.1 (Kearse et al., 2012).

For every mound, the social structure result obtained with the $G p-9^{b}$ method was confirmed using microsatellite markers, inferring whether all workers from a mound could be assigned to a single queen (carrying one of the two alleles of the mother queen at each microsatellite marker studied). Polygyny was deduced when more than one worker per colony could not be unambiguously assigned to a single queen (see Appendix S2 for results). In addition, we compared the relatedness coefficients $(r)$ between monogyne and polygyne mounds (as identified using $G p-9$ ) using analysis of variance (ANOVA) to verify that relatedness coefficients were significantly lower in polygyne versus monogyne mounds (i.e., suggesting the reproduction of several unrelated queens) and to determine any differences by site. We also used t-tests to establish if relatedness coefficients were significantly different from 0 for polygyne mounds (i.e., multiple unrelated queens producing workers within a single mound) and 0.75 for monogyne mounds (i.e., one singly-mated queen producing workers within a mound). Relatedness coefficients were calculated using the program COANCESTRY v.1.0 (Wang, 2011), according to the algorithm described by Queller and Goodnight (1989). Relatedness coefficients were weighted equally and standard errors (SE) were obtained by jackknifing over colonies.

Colony spatial structure was investigated for the six sites to determine whether distinct mounds of $S$. invicta, especially those collected within $5 \mathrm{~m}$ of each other, consisted of a single colony (i.e., polydomy) or separate colonies. To answer this question, genotypic frequencies at all mounds were compared using a log-likelihood (G)-based test of differentiation using GENEPOP ON THE WEB (Rousset, 2008). Bonferroni's correction was applied to account for multiple comparisons of all pairs (adjusted $P$-value $<0.0008$ ). Significance was determined using a Fisher's combined probability test.

Colony clustering was visualized for each site by plotting individuals on a principal component analysis (PCA) using the adegenet $\mathrm{R}$ package (Jombart, 2008). The clustering of mounds into distinct colonies was also represented by Bayesian assignments of individuals into genetic clusters (i.e., colonies; K) using STRUCTURE v.2.3.4 (Pritchard, Stephens, \& Donnelly, 2000). For each site, STRUCTURE simulations were run with values of $\mathrm{K}$ from 1 to the total number of mounds encountered in each site and repeated 10 times for each value of $\mathrm{K}$. Each run included a $5 \times 10^{4}$ burn-in period followed by $1 \times 10^{5}$ iterations of the MCMC. The most likely number of groupings was evaluated using the $\Delta \mathrm{K}$ method (Evanno, Regnaut, \& Goudet, 2005) implemented in Structure Harvester v.0.6.8 (Earl, 2012). Additional details and results for clustering analysis can be found in Appendix S2 and S3.

\section{Data analysis}

We used logistic regression to determine the effects of spatial distance, genetic differentiation (using pairwise $F_{S T}$ values), social form, within-mound relatedness coefficients between workers, and site on whether or not untreated mounds shared with the treated mound. To do this, we constructed generalized linear models with a binomial distribution using the $g l m$ function in base R statistical software v3.6.1 (R Core Team, 2019). Distance from the treated mound, pairwise $\mathrm{F}_{\mathrm{ST}}$ values (compared between the treated and untreated mounds), social form of both treated and untreated mounds (i.e., monogyne or polygyne), within-mound relatedness coefficients between workers in both treated and untreated mounds, and site were treated as independent variables. The sharing status of the untreated mounds (i.e., "shared with the treated mound" or "did not share with the treated mound") was the dependent, binary variable. Mounds that were identi- 
fied as having shared with the treated mound had $\delta^{15} \mathrm{~N}$ values greater than 20these values were far higher than any natural abundance isotope values observed at our field sites (mean natural abundance $\delta^{15} \mathrm{~N}$ values before tracer treatment: $5.00 \delta^{15} \mathrm{~N}$ values greater than 20 freely exchanging workers and/or resources with the treated mound. All other mounds were designated as "did not share with the treated mound." All plots were generated using ggplot2 (Wickham, 2016).

\section{Within-colony relatedness of fire ants in the literature}

We also compiled all published coefficients of within-colony relatedness between workers in the red imported fire ant to compare our results with those in the literature. We searched the Web of Science using the following search terms: "Solenopsis invicta" OR "red imported fire ant" AND population AND microsatellite . Our search generated 87 records, but a large number of these studies focused on a different ant or social insect species. We excluded any study that contained only queen-queen relatedness coefficients, as well as, any study of a different species of ant or social insect. We reviewed each record and extracted within-colony relatedness coefficients between workers (means and standard error whenever available) and recorded the sampling location. In total, we extracted information from eight studies.

\section{Within-colony sharing}

To evaluate within-colony sharing, we conducted a laboratory experiment testing polygyne worker discrimination between larvae that are close siblings and larvae that are not siblings (Fig 2). To do this, we established six single-lineage experimental colonies by collecting mated polygyne queens following mating flights. Fire ant queens are typically singly mated (Ross, 1993; Ross \& Fletcher, 1985; but see Fritz, Vander Meer, \& Preston, 2006; Lawson, Vander Meer, \& Shoemaker, 2012), so by maintaining colonies with an individual queen (rather than several queens), we were able to test worker discernment between brood that are close siblings (i.e., from the same mother) and brood that are not close siblings (i.e., from a different mother).

All colonies were kept in standardized laboratory conditions for at least two years to ensure they were large enough to be divided into smaller experimental colonies. Colonies were confirmed as the polygyne social form by screening workers for the presence of the $G p-9^{b}$ allele using the same methods as described above (see Genetic analysis in the methods section). Once incipient colonies were large enough, we used food dye to label the brood of each colony. We dyed brood by giving workers two separate tubes of $15 \mathrm{~mL}$ of water and $15 \mathrm{~mL}$ of artificial nectar each containing $0.9 \mathrm{ml}$ of food coloring (McCormick(r) Food Colors \& Egg Dye, McCormick \& Company, Inc., 18 Loveton Circle, Sparks, MD). We gave three colonies (colonies A, B, and C) yellow food coloring and three colonies (colonies D, E, and F) green food coloring (Table 1; Fig 2). Colors were randomly assigned. During this six-day period of brood dyeing, we did not give the ants any proteinaceous food so that dye would be highly visible in the guts of larvae.

Next, we created experimental colonies by combining $0.1 \mathrm{~g}$ of workers ( $\sim 120$ workers) with 50 larvae from the same natal colony as the workers (i.e., close siblings) and 50 larvae from a different colony (i.e., not siblings; see Table 1 for complete family combinations). Not all permutations of families were logistically possible in this experiment, so only larval combinations of different colors were combined so that all possible two-color combinations were created (Table 1). In all, there were 18 experimental colonies.

To quantify the feeding of larvae by workers, experimental colonies were given $7.5 \mathrm{ml}$ artificial nectar containing $0.2 \mathrm{~g}$ of non-toxic, fluorescent dye (DFDRY-C0 UV Dye from Risk Reactor, 2676 S. Grand Ave., Santa Ana, CA) for 18 hours. After 18 hours, we recorded the number of larvae remaining from each family and used a black light to count the number of larvae from each family fed the fluorescent dye. In order to ensure accurate results for potentially variable behaviors, data for experimental colonies were averaged across the three iterations of this experiment. This allowed us to remove within colony temporal variation and estimate the general behaviors of each experimental colony instead of only looking at a single snapshot of their behavior.

All data were analyzed using $\mathrm{JMP}^{(\mathrm{r})}$ 9. Percentage data were arcsine-square-root transformed. All graphs 
were produced with untransformed data. A more detailed description of the methods can be found in Appendix S4.

\section{Results}

\section{Between-mound sharing and colony genetic structure}

All treated mounds showed elevated $\delta^{15} \mathrm{~N}$ values, indicating that our methods were successful in enriching the isotope values of individual mounds. Counter to our expectations, treated mounds shared very little with neighboring mounds, regardless of social form (Fig 3) and within-mound relatedness between workers (Appendix S5). Six of the 57 untreated mounds showed evidence of sharing with the treated mound (three monogyne and three polygyne). Sharing was independent of the social form of the treated mound $\left(\chi^{2}=\right.$ $0.0091, \mathrm{df}=1, P=0.924)$, the social form of the untreated mound $\left(\chi^{2}=0.0001, \mathrm{df}=1, P=0.992\right)$, and by the interaction between these variables $\left(\chi^{2}=0.0061, \mathrm{df}=1, P=0.938\right)$. Moreover, sharing was independent of within-mound relatedness between workers in the treated mound $\left(\chi^{2}=0.0681\right.$, $\left.\mathrm{df}=1, P=0.794\right)$, by relatedness between workers in the untreated mound $\left(\chi^{2}=0.7718, \mathrm{df}=1, P=0.380\right)$, and by the interaction between these variables $\left(\chi^{2}=0.000, \mathrm{df}=1, P=1.000\right)$.

There was a significant effect of distance on whether or not sharing was detected in untreated mounds $\left(\chi^{2}=\right.$ $10.0858, \mathrm{df}=1, P=0.001)$. All untreated mounds with elevated $\delta^{15} \mathrm{~N}$ values were within $5 \mathrm{~m}$ of the treated mound (Fig 4a). However, not all mounds within $5 \mathrm{~m}$ of the treated mound shared (Appendix S6), indicating that distance was not the only component influencing sharing between mounds. There were 13 untreated mounds within $5 \mathrm{~m}$ from the treated mound that did not share with the treated mound, one of which was only $0.4 \mathrm{~m}$ from the treated mound. Sharing between mounds did not vary by site $\left(\chi^{2}=2.0408, \mathrm{df}=5, P\right.$ $=0.843)$.

Treated mounds were more genetically similar to the untreated mounds with which they shared compared to those with which they did not share. Pairwise $F$ sT values between the treated and untreated mounds were significantly lower on average and near zero in mounds that shared (mean and standard errors: $0.028 \pm$ $0.015)$ than in mounds that did not share $\left(0.228 \pm 0.021 ; \chi^{2}=14.5562\right.$, df $=1, P<0.001 ;$ Fig $\left.4 \mathrm{~b}\right)$ where $F$ $\mathrm{ST}_{\mathrm{S}}$ were equivalent to $F \mathrm{ST}_{\mathrm{S}}$ between different colonies. Likewise, untreated mounds that shared could not be significantly genetically differentiated from the treated mound according to the log-likelihood $(\mathrm{G})$-based test of differentiation. There was no significant interaction between distance and pairwise $F$ ST values $\left(\chi^{2}\right.$ $=0.3395, \mathrm{df}=1, P=0.560)$. Pairwise $F$ st between polygyne mounds within each site was lower than between monogyne mounds (mean and standard errors of $0.144 \pm 0.008$ and $0.356 \pm 0.010$ respectively), but there was no significant interaction between pairwise $F$ sT and social form $\left(\chi^{2}=0.0000, \mathrm{df}=3, P=\right.$ 1.000) on sharing between mounds.

\section{Within-colony relatedness and comparison with the literature}

At our sites, within-mound relatedness was significantly higher in monogyne mounds (mean and standard errors: $0.644 \pm 0.024)$ than in polygyne mounds $\left(0.269 \pm 0.037 ; \mathrm{F}_{1,60}=75.832, P<0.001\right)$. However, relatedness in polygyne mounds at our sites was significantly greater than zero $\left(\mathrm{t}_{33}=7.249, P<0.001 ; 95 \%\right.$ CI: 0.193-0.344). Relatedness in monogyne mounds was significantly lower than $0.75\left(\mathrm{t}_{35}=-4.368, P<0.001\right.$; 95\% CI: 0.595-0.693), consistent with our genetic results showing that some colonies (18/38) were headed by a multiply mated queen (Appendix S7), as has been reported previously (Fritz, Vander Meer, \& Preston, 2006; Lawson, Vander Meer, \& Shoemaker, 2012). Within-mound relatedness did not vary by site $\left(\mathrm{F}_{5,60}=\right.$ $1.781, P=0.130)$, nor did the within-mound relatedness of each social form vary by site $\left(\mathrm{F}_{3,60}=0.382, P\right.$ $=0.766)$.

Based on our analysis of within-colony relatedness coefficients between workers reported in the literature, no other study has analyzed within-colony relatedness between fire ant workers in Texas, USA (Fig 5). Of the five studies conducted in Georgia, USA, four reported coefficients in polygyne populations that were not significantly greater than zero, and one reported a coefficient that was significantly greater than zero (mean: 0.16; Ross et al. 1993; Fig 5). Studies conducted on introduced polygyne populations in Australia 
and Taiwan were greater than zero (Richlands, Australia: 0.246; Chiayi, Taiwan: 0.1444; Taoyuan, Taiwan: 0.1122). Likewise, coefficients of polygyne fire ants in their native range of Argentina were also greater than zero (Corrientes: 0.24; Formosa: 0.15).

\section{Within-colony sharing}

After 18 hours in experimental colonies with workers, significantly more brood from the same mother remained compared with brood from a different mother (Fig 6a; two-tailed t-test: $\mathrm{t}_{17}=5.2284, P<0.001$ ). The number of brood from a different mother diminished by $27 \%$ while the brood from the same mother diminished by only $14 \%$. No dead larvae were found in the colonies.

Likewise, the feeding of larvae by workers differed depending on the relationship between workers and brood. A higher percentage of brood from the same mother as the workers were fed compared with brood from a different mother (Fig 6b; two-tailed t- test: $\mathrm{t}_{17}=5.3881, P<0.001$ ).

\section{Discussion}

Here we provide evidence that polygyne fire ant colonies in Texas are not unicolonial and may engage in low levels of nepotism. Polygyne colonies did not exchange resources or workers, indicating that they maintain strict colony boundaries (Fig 3). Polygyne workers also preferentially fed larval siblings and may have cannibalized non-siblings during times of stress (Fig 6), suggesting that within-colony conflict exists. Our behavioral results also corresponded with higher levels of within-mound relatedness between workers in the field than those previously reported in North America (Fig 5; but see Ross, 1993). Our results suggest that polygyne fire ant colonies are actually multicolonial and may engage in high levels of intraspecific competition in at least parts of their introduced range (Weeks, Wilson, \& Vinson, 2004).

Counter to our expectations, we detected distinct colony boundaries between almost all mounds in the field regardless of social form (i.e., polygyne mounds were no more likely to share than monogyne mounds; Fig 3) and within-mound relatedness between workers (Appendix S5). The mounds that did share with each other were likely part of the same polydomous colony based on genetic results and spatial distance between mounds (Fig 4). Although our results seem to run counter to previous assumptions about polygyne fire ants (e.g., Greenberg et al., 1992; Holway et al., 2002; Morel et al., 1990; Plowes et al., 2007; Porter et al., 1992; Vander Meer et al., 1990), several other studies have found evidence of boundaries at least on some level between polygyne colonies (Goodisman et al., 2007; Krushelnycky et al., 2010; Weeks et al., 2004). For example, polygyne mounds in Georgia, USA, showed distinct genotypic frequencies and worker weight profiles, suggesting that workers and queens are not moving freely between mounds (Goodisman et al., 2007). Moreover, although polygyne workers do not aggressively attack non-nestmates like their monogyne counterparts (Vander Meer et al., 1990), workers will antennate and occasionally bite non-nestmates in the laboratory, indicating well-developed nestmate recognition (Obin, Morel, \& Vander Meer, 1993). There is also evidence of exploitative competition between polygyne mounds in the field (Weeks et al., 2004).

Our results confirm that polygyne mounds located near each other are not completely interconnected (Goodisman et al., 2007; Krushelnycky et al., 2010; Weeks et al., 2004); in fact, polygyne mounds in our study were just as isolated as monogyne mounds. Moreover, boundaries appear to be present at relatively small spatial scales, as many mounds of both social forms did not exchange resources despite being within $5 \mathrm{~m}$, and sometimes even less than 1m, from each other (Appendix S6). Weeks et al. (2004) found that most labeled polygyne fire ant workers remained within $4 \mathrm{~m}$ of their colony. In our study, we found mounds with distinct boundaries separated by less than $1 \mathrm{~m}$, suggesting mounds very close to each other may belong to different colonies. These results imply that fire ants are able to distinguish nestmates from non-nestmates, even when environmental odor cues may be similar from living in close proximity. Heritable and environmental odor cues are thought to be additive in fire ants, but monogyne and polygyne fire ant workers have been shown to distinguish nestmate from non-nestmate despite similar environmental odor cues (Obin et al., 1993; Obin, 1986).

Our laboratory experiment provides further evidence that polygyne fire ants are not as cooperative as 
previously assumed, as workers preferentially fed sibling over non-sibling brood (Fig 6a). Workers may have even preferentially cannibalized non-sibling brood, because there was a significantly greater reduction in the number of non-sibling brood remaining at the end of the experiment compared with sibling brood (Fig 6b). All colonies were kept in standardized laboratory conditions and fed standardized diets to minimize acquired, environmental identification cues (Obin et al., 1993), so worker recognition of sibling over nonsibling larvae is likely based on heritable as opposed to environmental odor cues. One reason for the greater disappearance of non-sibling brood could be due to differential brood viability between families, which can cause "sham nepotism" (Holzer, Kümmerli, Keller, \& Chapuisat, 2006). We believe this scenario is unlikely, however, given the short time frame and reciprocal nature of our experiment. Furthermore, queens allowed to found in isolation do not express differential viability of offspring (Vargo \& Ross, 1989). Larvae were given to the colonies by placing them outside of the nest dishes and allowing the workers to bring them into the nest, so it is also possible that workers collected greater numbers of sibling brood than non-sibling brood. We found no desiccated larvae, however, in or around the experimental colonies. Instead, we hypothesize that polygyne fire ant workers preferentially cannibalize less related brood in times of stress. High levels of cannibalism are known from this species (Sorensen, Busch, \& Vinson, 1983; Tschinkel, 1993) and often occur when resources are in short supply (e.g., a lack of proteinaceous food). Any hereditary predisposition towards nepotism should be under positive selection in a eusocial system, as preferential care of related offspring should increase inclusive fitness (Keller, 1997; Wilson, 2008; Wilson \& Hölldobler, 2005). However, extremes in nepotism should be selected against in polygyne systems (Keller, 1997), as they tend to create an environment of competition within the colony and diminish colony fitness. While strong nepotism should be selected against, slightly nepotistic ants may have an advantage over their less discriminating counterparts as nepotism toward sexual larvae, regardless of the strength of the interaction, should increase inclusive fitness (Nonacs, 1988). This would suggest that eusociality should favor low levels of nepotism, such as those found in this study, which straddles the gap between selfless and selfish endeavors.

The lack of sharing between polygyne colonies in the field and evidence of within-colony nepotism in the laboratory corresponds with high relatedness coefficients observed in the field. Although relatedness between workers was lower within polygyne mounds than within monogyne mounds, relatedness coefficients in polygyne mounds were much higher (mean and standard errors: $0.269 \pm 0.037$ ) than those previously observed in other introduced populations in the USA (Fig 5; DeHeer \& Ross, 1997; Goodisman et al., 2007; Ross, 1993; Ross \& Fletcher, 1985; Ross et al., 1996). Past studies have reported values that were not significantly different from zero (i.e., many unrelated queens producing workers within the same mound; but see Ross, 1993), but our results suggest that workers within polygyne mounds in Texas may even be half-sisters (expected $r$ for half-sisters $=0.25$ ). One explanation is that the polygyne mounds that we surveyed contained fewer queens than those sampled in past studies. Ross (1993) demonstrated that relatedness between workers within polygyne mounds in Georgia was negatively correlated with queen number. Geographic variation in colony genetic structure may also explain the higher within-mound relatedness and pairwise $F$ sT values in polygyne mounds compared with those in other states (DeHeer \& Ross, 1997; Goodisman et al., 2007; Ross \& Fletcher, 1985; Ross et al., 1996; but see Ross, 1993). Much of the population genetics data of introduced polygyne fire ants in the USA has focused on one or a few geographic regions (DeHeer \& Ross, 1997; Ross, 1993; Ross \& Fletcher, 1985; Ross \& Keller, 1995; Ross et al., 1996). Although fire ant populations in Texas have been shown to vary genetically from other parts of the country (Shoemaker, Deheer, Krieger, \& Ross, 2006), only a few studies have examined colony genetic structure in Texas (Chen, Lu, Skow, \& Vinson, 2003; Ross, Vargo, Keller, \& Trager, 1993; Ross et al., 1996), and none that we know of have reported within-colony relatedness between workers (Fig 5).

It is also possible that colony genetic structure has changed over time. For example, relatedness was almost twice as high in older compared with younger populations (i.e., over 100 years old vs. 17 years old) in the polygyne ant Formica fusca (Hannonen, Helanterä, \& Sundström, 2004). Past studies of polygyne fire ant queens in Texas reported a near zero relatedness between co-occurring queens (Chen et al., 2003; Ross et al., 1996), which should result in similarly low relatedness between workers, but it is possible that withincolony relatedness has increased over the past 20 years. The ecological impact of polygyne fire ants weakened 
significantly over a 10-year period in parts of Texas (Morrison, 2002), which may have corresponded with a change in genetic structure. Interestingly, our relatedness coefficients between workers were much more similar to those reported in native polygyne fire ant populations (Fig 5; Ross et al., 1996). In these native populations, polygyne colonies are multicolonial; nestmate queens are highly related (Ross et al., 1996), workers recognize nestmate from non-nestmate (Chirino, Gilbert, \& Folgarait, 2012), and colony densities are 4-7 times lower than those observed throughout North America (Porter, Williams, Patterson, \& Fowler, 1997). Although we did not measure relatedness between nestmate queens, our behavioral results in the field and in the laboratory support the conclusion that polygyne fire ants in Texas likely function similarly to native conspecifics, in that colonies are likely multicolonial and engage in high levels of intraspecific competition. Our within-mound relatedness coefficients between polygyne workers were also similar to those reported in Australia (Fig 5; Henshaw, Kunzmann, Vanderwoude, Sanetra, \& Crozier, 2005), so it would be interesting to determine if Australian polygyne fire ant colonies behave similarly to those in Texas and in the native range.

This does not explain, however, why some studies have detected colony boundaries despite very low relatedness between polygyne fire ant mounds (e.g., Goodisman et al., 2007). Our results suggest that relatedness alone does not predict sharing between mounds, as several neighboring mounds had low pairwise $F$ sT and relatedness values but did not share with each other (Appendix S6). In other ant species, kinship does not always correlate with cooperation between nests (Procter et al., 2016). For example, nests of the polygyne antFormica lugubris did not share workers or resources with each other despite high genetic relatedness (Procter et al., 2016). Similarly, Argentine ants (L. humile ) did not freely exchange workers between all nests within a single supercolony, even though there were no detectable genetic differences between nests (Heller et al., 2008). Likewise, gene flow was limited and some workers were unexpectedly aggressive towards each other within the same supercolony in the unicolonial ant Formica pressilabris, suggesting that supercolonies do not always function as a single unit (Hakala, Ittonen, Seppä, \& Helanterä, 2020). This highlights the importance of quantifying colony boundaries using several different methods (Ellis et al., 2017), as genetic relationships do not always imply a free exchange of workers or resources. Low relatedness among nestmate workers may also result from extreme polygyny, where workers originate from numerous unrelated queens (Keller 1995). In this case, each polygyne colony can contain as much genetic diversity as the background population, with nestmate workers being as related to each other than to any random worker within this population, leading to a zero relatedness within the colony (Queller and Goodnight 1989). Future research should examine the exchange of resources between polygyne fire ant mounds in other parts of their invaded range where within-mound relatedness has been reported to be much lower to ultimately determine the relationship between sharing and genetic relatedness.

Our study tests fundamental assumptions about the role of inter- and intracolonial cooperation in polygyne fire ant abundance. Polygyne fire ants are highly abundant throughout their invaded range (Porter et al., 1991), but our results suggest that their high abundance is not due to higher levels of cooperation between neighboring colonies, at least in parts of Texas. Moreover, workers appear to preferentially direct care towards more related brood, indicating some level of nepotism within multiple-queen colonies. Our results add to a growing body of evidence that unicoloniality does not always explain invasive ant abundance (e.g., Eyer et al., 2020; Garnas, Drummond, \& Groden, 2014; Zhang et al., 2019). Other factors such as dietary flexibility, competition with other species, and abiotic features may be more important to invasions than intraspecific cooperation in some species. Future research should further examine the relationship between unicoloniality and ant invasions by directly quantifying sharing between nests in the field. Identifying the factors that promote invasive ant success is critical to understanding and managing their ecological impacts.

\section{Acknowledgements}

We would like to thank R. Puckett for help with field sites and comments on an earlier draft of this manuscript, B. Reid and W. Welch for providing access to Coulter Field, J. Underwood, M. Arceneaux and C. Webb for their help sampling, P. Lenhart, L. Garcia, W. Sconiers, E. Bockoven, P. Aranda, B. Elkins, J. Hewlett, and C. Lin for helping to maintain the fire ant colonies and overall support for the project, and J. Light 
and G. Sword for helpful comments on an earlier draft of this manuscript. This material is based upon work supported by the Texas A\&M AgriLife Research Invasive Ant Research and Management Grant, the Texas Ecolab Program, a fellowship from Texas A\&M University, and the National Science Foundation Graduate Research Fellowship under Grant No. DGE 1252521. It was also supported by the Sid Kyle Endowment in the Department of Ecosystem Science and Management at Texas A\&M University and the Urban Entomology Endowment at Texas A\&M University. Any opinion, findings, and conclusions or recommendations expressed in this material are those of the authors and do not necessarily reflect the views of the National Science Foundation.

\section{References}

Allen, C. R., Epperson, D. M., \& Garmestani, A. S. (2004). Red imported fire ant impacts on wildlife: a decade of research. The American Midland Naturalist, 152 (1), 88-103. doi:10.1674/00030031(2004)152[0088:rifaio]2.0.co;2

Berman, M., Andersen, A., Hély, C., \& Gaucherel, C. (2013). Overview of the distribution, habitat association and impact of exotic ants on native ant communities in New Caledonia. PLoS One, 8 (6), e67245.

Bhatkar, A., \& Vinson, S. (1987). Colony limits in Solenopsis invicta Buren (J. Eder \& H. Rembold Eds.): Verlag J. Peperny.

Björkman-Chiswell, B., Van Wilgenburg, E., Thomas, M., Swearer, S., \& Elgar, M. (2008). Absence of aggression but not nestmate recognition in an Australian population of the Argentine ant Linepithema humile .Insectes Sociaux, 55 (2), 207-212.

Boomsma, J. J., \& d'Ettorre, P. (2013). Nice to kin and nasty to non-kin: revisiting Hamilton's early insights on eusociality.Biology Letters, 9 (6), 20130444.

Boulay, R., Arnan, X., Cerdá, X., \& Retana, J. (2014). The ecological benefits of larger colony size may promote polygyny in ants. Journal of Evolutionary Biology, 27 (12), 2856-2863.

Boutin-Ganache, I., Raposo, M., Raymond, M., \& Deschepper, C. F. (2001). M13-tailed primers improve the readability and usability of microsatellite analyses performed with two different allele-sizing methods. Biotechniques, 31 (1), 25-28.

Buczkowski, G., \& Silverman, J. (2005). Context-dependent nestmate discrimination and the effect of action thresholds on exogenous cue recognition in the Argentine ant. Animal Behaviour, 69 (3), 741-749.

Chen, Y., Lu, L., Skow, L., \& Vinson, S. (2003). Relatedness among co-existing queens within polygyne colonies of a Texas population of the fire ant, Solenopsis invicta . Southwestern Entomologist, 28 (1), 27-36.

Chirino, M. G., Gilbert, L. E., \& Folgarait, P. J. (2012). Behavioral discrimination between monogyne and polygyne red fire ants (Hymenoptera: Formicidae) in their native range. Annals of the Entomological Society of America, 105 (5), 740-745.

Coplen, T. B. (2011). Guidelines and recommended terms for expression of stable-isotope-ratio and gas-ratio measurement results. Rapid Communications in Mass Spectrometry, 25 (17), 2538-2560.

Crozier, R., \& Pamilo, P. (1996). One into two will go. Nature, 383 (6601), 574-575.

DeHeer, C. J., \& Ross, K. G. (1997). Lack of detectable nepotism in multiple-queen colonies of the fire ant Solenopsis invicta(Hymenoptera: Formicidae). Behavioral Ecology and Sociobiology, 40 (1), 27-33.

Earl, D. A. (2012). STRUCTURE HARVESTER: a website and program for visualizing STRUCTURE output and implementing the Evanno method. Conservation Genetics Resources, 4 (2), 359-361.

Ellis, S., Procter, D., Buckham-Bonnett, P., \& Robinson, E. J. H. (2017). Inferring polydomy: a review of functional, spatial and genetic methods for identifying colony boundaries. Insectes Sociaux, 64 (1), 19-37. 
Evanno, G., Regnaut, S., \& Goudet, J. (2005). Detecting the number of clusters of individuals using the software STRUCTURE: a simulation study. Molecular Ecology, 14 (8), 2611-2620.

Eyer, P.-A., Espinoza, E. M., Blumenfeld, A. J., \& Vargo, E. L. (2020). The underdog invader: Breeding system and colony genetic structure of the dark rover ant (Brachymyrmex patagonicus Mayr). Ecology and Evolution, 10 (1), 493-505.

Eyer, P.-A., McDowell, B., Johnson, L. N., Calcaterra, L. A., Fernandez, M. B., Shoemaker, D., . . Vargo, E. L. (2018). Supercolonial structure of invasive populations of the tawny crazy ant Nylanderia fulvain the US. BMC Evolutionary Biology, 18 (1), 209.

Fritz, G. N., Vander Meer, R. K., \& Preston, C. A. (2006). Selective male mortality in the red imported fire ant, Solenopsis invicta .Genetics, 173 (1), 207-213.

Fry, B. (2006). Stable isotope ecology (Vol. 521): Springer.

Garnas, J. R., Drummond, F. A., \& Groden, E. (2014). Intercolony aggression within and among local populations of the invasive ant,Myrmica rubra (Hymenoptera: Formicidae), in coastal Maine.Environmental Entomology, 36 (1), 105-113.

Giraud, T., Pedersen, J. S., \& Keller, L. (2002). Evolution of supercolonies: the Argentine ants of southern Europe. Proceedings of the National Academy of Sciences, 99 (9), 6075-6079.

Goodisman, M. A., Sankovich, K. A., \& Kovacs, J. L. (2007). Genetic and morphological variation over space and time in the invasive fire antSolenopsis invicta . Biological Invasions, 9 (5), 571-584.

Gotzek, D., Shoemaker, D. D., \& Ross, K. G. (2007). Molecular variation at a candidate gene implicated in the regulation of fire ant social behavior. PLoS One, 2 (11), e1088.

Greenberg, L., Vinson, S., \& Ellison, S. (1992). Nine-year study of a field containing both monogyne and polygyne red imported fire ants (Hymenoptera: Formicidae). Annals of the Entomological Society of America, $85(6), 686-695$.

Hakala, S. M., Ittonen, M., Seppä, P., \& Helanterä, H. (2020). Limited dispersal and an unexpected aggression pattern in a native supercolonial ant. Ecology and Evolution, 10 (8), 3671-3685.

Hamilton, W. D. (1964). The genetical evolution of social behaviour. II. Journal of Theoretical Biology, 7 (1), 17-52.

Hanna, C., Cook, E. D., Thompson, A. R., Dare, L. E., Palaski, A. L., Foote, D., \& Goodisman, M. A. (2014). Colony social structure in native and invasive populations of the social wasp Vespula pensylvanica .Biological Invasions, 16 (2), 283-294.

Hannonen, M., Helanterä, H., \& Sundström, L. (2004). Habitat age, breeding system and kinship in the ant Formica fusca .Molecular Ecology, 13 (6), 1579-1588.

Helanterä, H., Strassmann, J. E., Carrillo, J., \& Queller, D. C. (2009). Unicolonial ants: where do they come from, what are they and where are they going? Trends in Ecology 83 Evolution, 24 (6), 341-349.

Heller, N., Ingram, K., \& Gordon, D. (2008). Nest connectivity and colony structure in unicolonial Argentine ants. Insectes Sociaux, 55 (4), 397-403.

Henshaw, M. T., Kunzmann, N., Vanderwoude, C., Sanetra, M., \& Crozier, R. H. (2005). Population genetics and history of the introduced fire ant, Solenopsis invicta Buren (Hymenoptera: Formicidae), in Australia. Australian Journal of Entomology, 44 (1), 37-44.

Holway, D. A. (1998). Effect of Argentine ant invasions on ground-dwelling arthropods in northern California riparian woodlands. Oecologia, 116 (1-2), 252-258. 
Holway, D. A., Lach, L., Suarez, A. V., Tsutsui, N. D., \& Case, T. J. (2002). The causes and consequences of ant invasions. Annual Review of Ecology and Systematics, 33 (1), 181-233. doi:10.1146/annurev.ecolsys.33.010802.150444

Holway, D. A., \& Suarez, A. V. (2004). Colony-structure variation and interspecific competitive ability in the invasive Argentine ant.Oecologia, 138 (2), 216-222.

Holzer, B., Kümmerli, R., Keller, L., \& Chapuisat, M. (2006). Sham nepotism as a result of intrinsic differences in brood viability in ants. Proceedings of the Royal Society B: Biological Sciences, 273 (1597), 2049-2052.

Jombart, T. (2008). adegenet: a R package for the multivariate analysis of genetic markers. Bioinformatics, 24 (11), 1403-1405.

Kearse, M., Moir, R., Wilson, A., Stones Havas, S., Cheung, M., Sturrock, S., . . . Drummond, A. (2012). Geneious Basic: An integrated and extendable desktop software platform for the organization and analysis of sequence data. Bioinformatics, 28 (12), 1647-1649.

Keller, L. (1995). Social life: the paradox of multiple-queen colonies. Trends in Ecology \& Evolution, 10 (9), 355-360.

Keller, L. (1997). Indiscriminate altruism: unduly nice parents and siblings. Trends in Ecology $\&$ Evolution, $12(3), 99-103$.

Korb, J., \& Foster, K. R. (2010). Ecological competition favours cooperation in termite societies. Ecology Letters, 13 (6), 754-760.

Krieger, M., \& Keller, L. (1997). Polymorphism at dinucleotide microsatellite loci in fire ant Solenopsis invicta populations. Molecular Ecology, 6 (10), 997-999.

Krieger, M. J., \& Ross, K. G. (2002). Identification of a major gene regulating complex social behavior. Science, 295 (5553), 328-332.

Krushelnycky, P. D., Holway, D. A., \& LeBrun, E. G. (2010). Invasion processes and causes of success. In L. Lach, C. L. Parr, \& K. L. Abbott (Eds.), Ant Ecology (pp. 245-260): Oxford University Press.

Lawson, L. P., Vander Meer, R. K., \& Shoemaker, D. (2012). Male reproductive fitness and queen polyandry are linked to variation in the supergene Gp-9 in the fire ant Solenopsis invicta. Proceedings of the Royal Society B: Biological Sciences, 279 (1741), 3217-3222.

LeBrun, E. G., Abbott, J., \& Gilbert, L. E. (2013). Imported crazy ant displaces imported fire ant, reduces and homogenizes grassland ant and arthropod assemblages. Biological Invasions, 15 (11), 2429-2442. doi:10.1007/s10530-013-0463-6

MacGown, J. A., Hill, J. G., \& Deyrup, M. A. (2007). Brachymyrmex patagonicus (Hymenoptera: Formicidae), an emerging pest species in the southeastern United States. Florida Entomologist, 90 (3), 457-464.

Mariotti, A. (1983). Atmospheric nitrogen is a reliable standard for ${ }^{15} \mathrm{~N}$ natural abundance measurements. Nature ,303 (5919), 685-687.

McGlynn, T. P. (1999). The worldwide transfer of ants: geographical distribution and ecological invasions. Journal of Biogeography ,26 (3), 535-548.

Morel, L., Vander Meer, R. K., \& Lofgren, C. S. (1990). Comparison of nestmate recognition between monogyne and polygyne populations ofSolenopsis invicta (Hymenoptera: Formicidae). Annals of the Entomological Society of America, 83 (3), 642-647.

Morrison, L. W. (2002). Long-term impacts of an arthropod-community invasion by the imported fire ant, Solenopsis invicta .Ecology, 83 (8), 2337-2345. 
Nonacs, P. (1988). Queen number in colonies of social Hymenoptera as a kin-selected adaptation. Evolution, $42(3), 566-580$.

Obin, M., Morel, L., \& Vander Meer, R. K. (1993). Unexpected, well-developed nestmate recognition in laboratory colonies of polygyne imported fire ants (Hymenoptera: Formicidae). Journal of Insect Behavior, 6 (5), 579-589.

Obin, M. S. (1986). Nestmate recognition cues in laboratory and field colonies of Solenopsis invicta buren (Hymenoptera: Formicidae). Journal of Chemical Ecology, 12 (9), 1965-1975.

Passera, L. (1994). Characteristics of tramp species. In D. F. Williams (Ed.), Exotic ants: biology, impact and control of introduced species (pp. 23-43): Westview Press.

Perdereau, E., Bagnères, A. G., Vargo, E., Baudouin, G., Xu, Y., Labadie, P., . . . Dedeine, F. (2015). Relationship between invasion success and colony breeding structure in a subterranean termite.Molecular Ecology, 24 (9), 2125-2142.

Plowes, R. M., Dunn, J. G., \& Gilbert, L. E. (2007). The urban fire ant paradox: native fire ants persist in an urban refuge while invasive fire ants dominate natural habitats. Biological Invasions, 9 (7), 825-836.

Porter, S., \& Savignano, D. (1990). Invasion of polygyne fire ants decimates native ants and disrupts arthropod community. Ecology, 71 (6), 2095-2106.

Porter, S. D., Bhatkar, A., Mulder, R., Vinson, B. S., \& Clair, D. J. (1991). Distribution and density of polygyne fire ants (Hymenoptera: Formicidae) in Texas. Journal of Economic Entomology, 84 (3), 866-874.

Porter, S. D., Fowler, H. G., \& Mackay, W. P. (1992). Fire ant mound densities in the United States and Brazil (Hymenoptera: Formicidae).Journal of Economic Entomology, 85 (4), 1154-1161.

Porter, S. D., Williams, D. F., Patterson, R. S., \& Fowler, H. G. (1997). Intercontinental differences in the abundance ofSolenopsis fire ants (Hymenoptera: Formicidae): escape from natural enemies? Environmental Entomology, 26 (2), 373-384.

Pritchard, J. K., Stephens, M., \& Donnelly, P. (2000). Inference of population structure using multilocus genotype data. Genetics, 155 (2), 945-959.

Procter, D. S., Cottrell, J. E., Watts, K., A'Hara, S. W., Hofreiter, M., \& Robinson, E. J. (2016). Does cooperation mean kinship between spatially discrete ant nests? Ecology and Evolution, 6 (24), 8846-8856.

Queller, D. C., \& Goodnight, K. F. (1989). Estimating relatedness using genetic markers. Evolution, 43 (2), $258-275$.

Queller, D. C., \& Strassmann, J. E. (1998). Kin selection and social insects. Bioscience, 48 (3), 165-175.

R Core Team (2019). R: a language and environment for statistical computing. R Foundation for Statistical Computing, Vienna, Austria.

Ross, K., Vargo, E., Keller, L., \& Trager, J. (1993). Effect of a founder event on variation in the genetic sex-determining system of the fire ant Solenopsis invicta. Genetics, 135 (3), 843-854.

Ross, K. G. (1993). The breeding system of the fire ant Solenopsis invicta : effects on colony genetic structure. The American Naturalist, 141 (4), 554-576.

Ross, K. G., \& Carpenter, J. M. (1991). Phylogenetic analysis and the evolution of queen number in eusocial Hymenoptera. Journal of Evolutionary Biology, 4 (1), 117-130.

Ross, K. G., \& Fletcher, D. J. (1985). Comparative study of genetic and social structure in two forms of the fire ant Solenopsis invicta(Hymenoptera: Formicidae). Behavioral Ecology and Sociobiology, 17 (4), 349-356.

Ross, K. G., \& Keller, L. (1995). Ecology and evolution of social organization: insights from fire ants and other highly eusocial insects.Annual Review of Ecology and Systematics, 26 (1), 631-656. 
Ross, K. G., \& Keller, L. (1998). Genetic control of social organization in an ant. Proceedings of the National Academy of Sciences, 95 (24), 14232-14237.

Ross, K. G., Vargo, E. L., \& Keller, L. (1996). Social evolution in a new environment: the case of introduced fire ants. Proceedings of the National Academy of Sciences, 93 (7), 3021-3025.

Rousset, F. (2008). genepop 007: a complete re-implementation of the genepop software for Windows and Linux. Molecular ecology resources, 8 (1), 103-106.

Schmid-Hempel, P. (1997). Infection and colony variability in social insects. In Infection, Polymorphism and Evolution (pp. 43-51): Springer.

Schmid-Hempel, P., \& Crozier, R. H. (1999). Ployandry versus polygyny versus parasites. Philosophical Transactions of the Royal Society of London. Series B: Biological Sciences, 354 (1382), 507-515.

Shoemaker, D. D., Deheer, C. J., Krieger, M. J., \& Ross, K. G. (2006). Population genetics of the invasive fire ant Solenopsis invicta(Hymenoptera: Formicidae) in the United States. Annals of the Entomological Society of America, 99 (6), 1213-1233.

Snyder, L. E. (1993). Non-random behavioural interactions among genetic subgroups in a polygynous ant. Animal Behaviour, 46 (3), 431-439.

Sorensen, A. A., Busch, T. M., \& Vinson, S. B. (1983). Factors affecting brood cannibalism in laboratory colonies of the imported fire ant, Solenopsis invicta Buren (Hymenoptera: Formicidae). Journal of the Kansas Entomological Society, 56(2), 140-150.

Tillberg, C. V., McCarthy, D. P., Dolezal, A. G., \& Suarez, A. V. (2006). Measuring the trophic ecology of ants using stable isotopes.Insectes Sociaux, 53 (1), 65-69.

Tschinkel, W. R. (1993). Resource allocation, brood production and cannibalism during colony founding in the fire ant, Solenopsis invicta . Behavioral Ecology and Sociobiology, 33 (4), 209-223.

Tschinkel, W. R. (2006). The fire ants : Harvard University Press.

Tsutsui, N. D., Suarez, A. V., Holway, D. A., \& Case, T. J. (2000). Reduced genetic variation and the success of an invasive species.Proceedings of the National Academy of Sciences of the United States of America, 97 (11), 5948-5953.

Valles, S. M., \& Porter, S. D. (2003). Identification of polygyne and monogyne fire ant colonies (Solenopsis invicta ) by multiplex PCR of Gp-9 alleles. Insectes Sociaux, 50 (2), 199-200.

Vander Meer, R., Obin, M., \& Morel, L. (1990). Nestmate recognition in fire ants: monogyne and polygyne populations. In R. Vander Meer, K. Jaffe, \& A. Cedeno (Eds.), Applied Myrmecology: A World Perspective (pp. 322-328): Westview Press.

Vargo, E. L., \& Ross, K. G. (1989). Differential viability of eggs laid by queens in polygyne colonies of the fire ant, Solenopsis invicta . Journal of Insect Physiology, 35 (7), 587-593.

Wang, J. (2011). COANCESTRY: a program for simulating, estimating and analysing relatedness and inbreeding coefficients. Molecular ecology resources, 11 (1), 141-145.

Wang, Z., Moshman, L., Kraus, E., Wilson, B., Acharya, N., \& Diaz, R. (2016). A review of the tawny crazy ant, Nylanderia fulva, an emergent ant invader in the southern United States: is biological control a feasible management option? Insects, 7 (4), 77.

Weeks, R. D., Wilson, L., \& Vinson, S. (2004). Resource partitioning among colonies of polygyne red imported fire ants (Hymenoptera: Formicidae). Environmental Entomology, 33 (6), 1602-1608.

Wickham, H. (2016). ggplot2: elegant graphics for data analysis : Springer. 
Wilson, E. E., Mullen, L. M., \& Holway, D. A. (2009). Life history plasticity magnifies the ecological effects of a social wasp invasion.Proceedings of the National Academy of Sciences, 106 (31), 12809-12813.

Wilson, E. O. (2008). One giant leap: how insects achieved altruism and colonial life. Bioscience, 58 (1), $17-25$.

Wilson, E. O., \& Hölldobler, B. (2005). Eusociality: origin and consequences. Proceedings of the National Academy of Sciences, 102 (38), 13367-13371.

Yang, C., Shoemaker, D. D., Wu, W.-J., \& Shih, C.-j. (2008). Population genetic structure of the red imported fire ant, Solenopsis invicta, in Taiwan. Insectes Sociaux, 55 (1), 54-65.

Zhang, Y. M., Vitone, T., Storer, C. G., Payton, A. C., Dunn, R. R., McDaniel, S. F., . . Lucky, A. (2019). From pavement to population genomics: characterizing a long-established non-native ant in North America through citizen science and ddRADseq. Frontiers in Ecology and Evolution, 7 , 453.

\section{Data Accessibility}

Microsatellite genotypes, within-mound relatedness coefficients, $F_{S T}$ values, and raw stable isotope data files will be uploaded onto Dryad upon acceptance.

\section{Author contributions}

MKK, MDE, and ELV conceived the study. MKK collected samples and conducted the stable isotope experiment with assistance from JTK, AH, TWB, and MDE. CCM and AAB conducted the nepotism study. PAE and JTK performed the genetic analyses. MKK and PAE analyzed the data. MKK wrote the paper with contributions from CCM, PAE, JTK, AH, TWB, ELV, and MDE.

\section{Tables}

Table 1. Single-lineage colony combinations to determine worker discrimination. Identity of the family (A, B, C, D, E, F), dyed color of the brood (yellow or green), and experimental colony combinations provided. Experimental colonies were constructed with $0.1 \mathrm{~g}$ workers $\left({ }^{\sim} 120\right)$ and 50 larvae (related brood) from the family indicated by the first letter in the experimental colony combinations. The second letter indicates the family of the other 50 larvae (unrelated brood).

\begin{tabular}{llll}
\hline & D (Green) & E (Green) & F (Green) \\
\hline A (Yellow) & AD, DA & AE, EA & AF, FA \\
B (Yellow) & BD, DB & BE, EB & BF, FB \\
C (Yellow) & CD, DC & CE, EC & CF, FC \\
\hline
\end{tabular}

\section{Figures}

Figure 1. Graphical representation of the methods used to quantify between-mound sharing in polygyne and monogyne fire ant mounds in the field.

\section{Hosted file}

image1.emf available at https://authorea.com/users/365629/articles/485656-do-polygyne-antscooperate-colony-boundaries-and-larval-discrimination-in-multiple-queen-colonies-of-thered-imported-fire-ant-solenopsis-invicta

Figure 2. Graphical representation of the methods used to quantify within-colony conflict in polygyne fire ants in the laboratory. All laboratory colonies were confirmed as the polygyne social form by screening workers for the presence of the $G p-g^{b}$ allele. Additional description of methods can be found in Appendix S4. Photos by A. A. Bockoven and C. C. McMichael.

\section{Hosted file}


image2.emf available at https://authorea.com/users/365629/articles/485656-do-polygyne-antscooperate-colony-boundaries-and-larval-discrimination-in-multiple-queen-colonies-of-thered-imported-fire-ant-solenopsis-invicta

Figure 3. Very few untreated mounds shared with treated mounds, regardless of social form. Plot includes the status of an isotope tracer in untreated mounds by social form according to $G p-9$ results. Mounds with $\delta^{15} \mathrm{~N}$ values greater than 20with the treated mound ("Shared with treated mound"), and the values of all other mounds indicated that untreated mounds did not exchange workers or resources with the treated mound ("Did not share with treated mound").

\section{Hosted file}

image3.emf available at https://authorea.com/users/365629/articles/485656-do-polygyne-antscooperate-colony-boundaries-and-larval-discrimination-in-multiple-queen-colonies-of-thered-imported-fire-ant-solenopsis-invicta

Figure 4. a) All untreated mounds that shared were within $5 \mathrm{~m}$ of the treated mound. Plot includes status of an isotope tracer in untreated mounds by distance in meters to the treated mound.b) All untreated mounds that shared showed very low pairwise $F$ sT values with the treated mound. Plot includes status of an isotope tracer in untreated mounds by pairwise $F_{\mathrm{ST}}$ values compared to the treated mound. Results shown are from all six sites. Point and error bars represent mean \pm SE. Mounds with $\delta^{15} \mathrm{~N}$ values greater than 20workers and/or resources with the treated mound ("Shared with treated mound"), and the values of all other mounds indicated that untreated mounds did not exchange workers or resources with the treated mound ("Did not share with treated mound").

\section{Hosted file}

image4.emf available at https://authorea.com/users/365629/articles/485656-do-polygyne-antscooperate-colony-boundaries-and-larval-discrimination-in-multiple-queen-colonies-of-thered-imported-fire-ant-solenopsis-invicta

Figure 5. Within-colony relatedness coefficients between workers of fire ants (Solenopsis invicta) by social form from multiple populations. Data based on results extracted from the literature and results in the present study. Points and error bars (when available) represent mean +- SE. Ref 1 = Goodisman et al. (2007);Ref $2=$ Ross (1993); Ref $3=$ Ross and Fletcher (1985);Ref $4=$ DeHeer and Ross (1997); Ref $5=$ Henshaw et al. (2005); Ref $6=$ Yang, Shoemaker, Wu, and Shih (2008); Ref $7=$ Ross et al. (1996); Ref 8 = Ross et al. (1993).

\section{Hosted file}

image5.emf available at https://authorea.com/users/365629/articles/485656-do-polygyne-antscooperate-colony-boundaries-and-larval-discrimination-in-multiple-queen-colonies-of-thered-imported-fire-ant-solenopsis-invicta

Figure 6. a) Number of brood remaining after 18 hours with workers. b) Percentage of brood fed after 18 hours with workers.

\section{Hosted file}

image6.emf available at https://authorea.com/users/365629/articles/485656-do-polygyne-antscooperate-colony-boundaries-and-larval-discrimination-in-multiple-queen-colonies-of-thered-imported-fire-ant-solenopsis-invicta 